\title{
THIN LAYER MODEL FOR SOLAR DRYING OF NAVEL AND MINNEOLA ORANGE SLICES
}

\author{
Amer, B. M. A. ${ }^{* 1,3}$ and Amer Eissa, A.H.,3
}

\begin{abstract}
Navel and Minneola orange slices at different thickness of 3, 6 and $9 \mathrm{~mm}$ were dried using a forced air solar dryer and have been examined nine drying models defining thin layer drying behavior of it using statistical analysis. Therefore, the drying models have been fitted to experimental data by means of the coefficients in these models. The results display that the regression analysis was performed using the experimental data to develop a thin layer drying model. The best fit of the thin layer drying of Navel and Minneola orange slices is obtained by two-term and Page equations were selected for the mathematical modeling based on the value of $R^{2}, \chi^{2}$ and RMSE. Both fitted models were validated against the experimental data.
\end{abstract}

Keywords: Navel, Minneola, modelling, solar, drying.

\section{INTRODUCTION}

range is one of the most commonly consumed fruits in the
world, being produced in almost all tropical countries,
(Rodriguez-Amaya, 1999; Sa'nchez-Moreno, Plaza, De Ancos, and Cano, 2003). The major growing regions include arid, semi-arid, humid subtropical and tropical areas. Some of the major producers are included among the arid and semi- arid subtropical areas, for instance California, Texas and Arizona in the US, countries in the Mediterranean Basin such as Spain, Italy, Greece, Egypt, Turkey or Morocco, and other producing regions such as Australia and northern South Africa (Davies, 1997).

Valencia and Navel oranges are a good source of vitamin C, fiber and folate. They also contain antioxidants that help boost immunity and they are most commonly used for their juice or be cooked or eaten fresh.

\footnotetext{
${ }^{1}$ Agriculture Engineering Department, Faculty of Agriculture, Cairo University, Egypt.

${ }^{2}$ Agriculture Engineering Department, Faculty of Agriculture, Minoufiya Uni., Shibin El-Kom, Egypt.

${ }^{3}$ Department of Agriculture Systems Engineering, College of Agricultural \& Food Sciences, King Faisal Uni., Saudi Arabia.
} 
PROCESS ENGINEERING

Use the juice and zest for marinades, syrups, vinaigrette, cocktails or to flavor sauces and custards.

Most Minneola fruit (Minneola tangelo citrus tangarina) are characterized by a stem-end neck which tends to make the fruit appear pear or bell-shaped. This appearance has given rise to the name Honeybell in the gift fruit trade, but the proper name remains Minneola, (Jackson and Futch, 2003).

Oranges are one of the fruits that present the highest losses by decomposition after cropping due to be extremely perishable and not allowing the use of freezing for its conservation.

Many mathematical models have been established to describe the drying processes (Turner and Mujumdar, 1997, Shi et al., 2013, Benhura, et al., 2014, Taghian Dinani et al., 2014, and Chimplee and Klinkesorn, 2015).

There are many researchers were studied the solar drying for many types of fruit such as Mahmutogla et al., (1996) for grapes, Gallali et al. (2000) for figs, El-Beltagy et al., (2007) for strawberry and Amer et al. (2010) for banana. Although, there are a few number of researches related to solar drying for oranges (Ben Slama and Combarnous, 2011) and for mathematical models (Garau, et al. 2006).

For this reason, this research carry out to develop a mathematical model for thin layer drying of Navel and Minneola orange slices and determine the parameters of the best suitable models for those orange slices.

\section{Solar dryer.}

\section{MATERIAL AND METHODS}

An experimental forced convection solar dryer was used to dry Navel and Minneola orange slices. It was constructed and located on the roof of the Agricultural System Engineering Dept., King Faisal University, ALHofuf, AL-Hassa, Saudi Arabia and was oriented so that collector faces south. The dryer consisted of a solar collector and a drying chamber and made from readily available local materials.

The components of the solar dryer were solar collector, drying chamber and chimney. The collector was inclined and has dimensions $(2 \times 1 \times 0.1$ $\mathrm{m})$ connected at the end with a vertical drying chamber $(1.2 \times 1 \times 1.35$ $\mathrm{m})$. There is a chimney over the drying chamber contained a fan to draw 
the ambient air inside the collector and to draw it after drying outside the drying chamber throw the chimney.

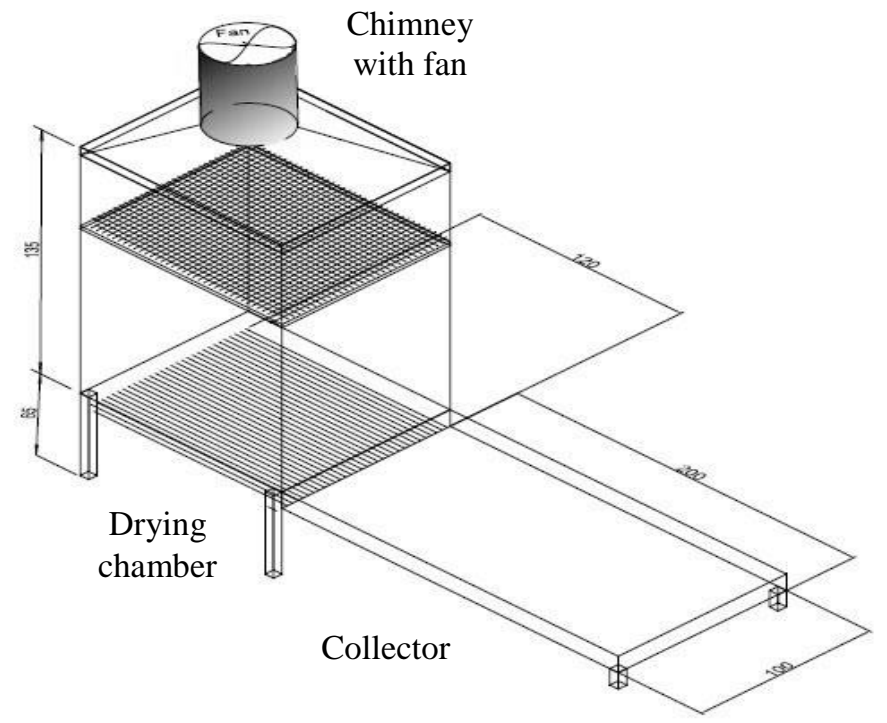

Fig. (1). Schematic diagram of solar drying system.

\section{Measurements.}

\subsection{Solar radiation and ambient air characteristics.}

The solar radiation and the ambient air characteristics (temperature, relative humidity and air velocity) were measured every $60 \mathrm{~min}$ by the weather station held in King Faisal University, AL-Hofuf, AL-Hassa, Saudi Arabia.

\subsection{Weight.}

Initial and final weights and weight changes during drying experiments of each sample were measured by a laboratory electric balance with accuracy of $0.001 \mathrm{gm}$.

\subsection{Moisture content.}

The moisture content of initial and final products was determined according to AOAC (2003). All moisture contents determination was carried out on three replicates for each sample. Moisture was determined on three replicates by desiccation at $105^{\circ} \mathrm{C}$ for $24 \mathrm{~h}$. 


\section{Solar drying experiments.}

The solar drying experiments Navel and Minneola orange slices were carried out during October and November, 2014 at AL-Hassa city, Saudi Arabia $\left(25^{\circ} 23^{\prime} \mathrm{N}, 49^{\circ} 35^{\prime} \mathrm{E}\right)$. The fresh fruit samples used in these experiments were purchased from a market located at this city. The samples were washed, manually peeled and quickly sliced to a thickness of (3, 6 and $9 \mathrm{~mm}$ thick-slices). The initial moisture content was determined as $78 \%$ wet basis, by using three samples were picked randomly from the fresh fruits slices.

The fresh fruits were spread evenly (single layer) with a near uniform distribution density on the drying trays. The loaded trays were then placed quickly in the drying chamber and the drying process started at 7.00 a.m and continued till 5.00 p.m.

Drying data were monitored using labeled samples, which were individually weighed and positioned on the trays. The weights of the labeled samples were recorded every one hour throughout the drying test. The drying test was terminated when the decrease in the weight of the samples had almost ceased. According to (AOAC, 2003) the final moisture content of the dried samples was determined. Moisture contents were reported as a percent wet basis and then converted to $\mathrm{kg}$ water $/ \mathrm{kg}$ dry matter for the modeling.

\section{Statistical analysis}

The data analysis of this experiment was carried out by using the Statistical Analysis System. Measured data were analyses by ANOVA. Least Significance Difference test was used to determine differences between means. Significance was assumed at $(\mathrm{P} \leq 0.05)$.

\section{Mathematical modelling of solar drying kinetics for orange slices}

Equation (1) is usually referred to as the exponential equation when written in a more general form:

$$
\frac{M-M_{e}}{M_{0}-M_{e}}=e^{-k t}
$$


An alternative approach to the analysis of thin layer drying has been to use empirical relationships. One equation that has been widely used in thin layer drying studies is Page's equation (Diamante and Murno, 1993; Madamba et al., 1996).

$$
\frac{M-M_{e}}{M_{0}-M_{e}}=e^{-k t^{n}}
$$

Where $(\mathrm{k}$ and $\mathrm{n})$ are constants.

$\left(M / M_{e}\right) /\left(M_{o} / M_{e}\right)$ was simplified as in equation (3) since relative humidity of the drying air continuously changed during the solar drying experiments, so the actual value of $M_{e}$ could not be determined. Also $M_{e}$ is small compared to $M$ or $M_{o}$, hence the error involved in the simplification is negligible (Doymaz and Pala, 2002)

$$
M R=\frac{M}{M_{0}}
$$

Non-linear regression was used to fit drying curves to the data based on the nine drying models, namely, the Newton $(\mathrm{N})$, Page $(\mathrm{P})$, Henderson \& Pabis (HP), Logarithmic (L), the Two-Term (TT), Wang \& Singh (WS), Midilli et al., modified Page (MP) and Modified Henderson \& Pabis (MHP) models are showed in Table 1.

The correlation coefficient (r) was one of the certain criteria to establish the best models to account for variation in the solar drying curves of the dried samples (Sarsavadia et al., 1999; Ozdemir and Devres, 1999). The coefficient of determination $\left(R^{2}\right)$, Chi-square $\left(\chi^{2}\right)$ and the root mean square error (RMSE) were used to evaluate the goodness of fit (Ertekin and Yaldiz, 2004; Ozdemir and Devres, 1999). The reduced Chi-square as the mean square of the deviations between the experimental and calculated values for the models was used. The regression analysis was performed using the SPSS.

These parameters were used to determine the goodness of the fit for the best models to describe the drying characteristics. The best results to fit the model could be determined when the coefficient of determination $\left(R^{2}\right)$ is high. Although, the better the goodness of the fit come when the 
lower values of the $\chi$-square and the root mean square error. This can be calculated as:

$$
\chi^{2}=\frac{\sum_{i=1}^{N}\left(M R_{\mathrm{exp}, i}-M R_{p r e, i}\right)^{2}}{N-n}
$$

the root mean square error $(R M S E)$ was calculated as:

$$
R M S E=\left[\frac{\sum_{i=1}^{N}\left(M R_{p r e, i}-M R_{\text {exp }, i}\right)^{2}}{N}\right]^{1 / 2}
$$

where $M R_{\exp , i}$ is the experimental moisture ratio, $M R_{\text {pre }, i}$ the predicted moisture ratio, $N$ the number of observations and $n$ the number of constants in the drying modal (Yaldiz et al., 2001).

\begin{tabular}{|c|c|c|c|}
\hline No. & Model \& Symbol & Model equation & References \\
\hline 1 & Newton $(N)$ & $\mathrm{MR}=\exp (-k . t)$ & $\begin{array}{c}\text { Doymaz \& Ismail } \\
(2011)\end{array}$ \\
\hline 2 & Page $(P)$ & $\mathrm{MR}=\exp \left(-k . t^{n}\right)$ & $\begin{array}{l}\text { Diamante et al., } \\
\text { (2010) }\end{array}$ \\
\hline 3 & $\begin{array}{c}\text { Henderson } \\
\text { and Pabis }(H P)\end{array}$ & $\mathrm{MR}=a \cdot \exp (-k . t)$ & $\begin{array}{c}\text { Diamante et al., } \\
\text { (2010) }\end{array}$ \\
\hline 4 & Logarithmic $(L)$ & $\mathrm{MR}=a \cdot \exp (-k . t)+c$ & $\begin{array}{c}\text { Yagciolu et al. } \\
\text { (1999) }\end{array}$ \\
\hline 5 & Two term $(T T)$ & $\begin{array}{c}\mathrm{MR}=a \cdot \exp \left(-k_{0 .} t\right)+ \\
b \cdot \exp \left(-k_{1} t\right)\end{array}$ & $\begin{array}{c}\text { Togrul \& Pehlivan, } \\
\text { (2004) }\end{array}$ \\
\hline 6 & $\begin{array}{c}\text { Wang and Singh } \\
(W S)\end{array}$ & $\mathrm{MR}=1+a . t+b . t^{2}$ & $\begin{array}{c}\text { Doymaz \& Ismail } \\
(\mathbf{2 0 1 1}) \\
\end{array}$ \\
\hline 7 & Midilli et al. (M) & $M R=a \exp \left(-k . t^{n}\right)+(b . t)$ & Midilli et al. (2002) \\
\hline 8 & Modified Page (MP) & $M R=\exp \left(-(k * t)^{n}\right)$ & Goyal et al. (2007). \\
\hline 9 & $\begin{array}{c}\text { Modified Henderson } \\
\text { \& Pabis }(M H P)\end{array}$ & $\begin{array}{l}\mathrm{MR}=a \cdot \exp (-k . t)+b . \\
\exp (-g . t)+c \cdot \exp (-h . t)\end{array}$ & Karathanos (1999) \\
\hline
\end{tabular}

Table (1). List of mathematical models for thin layer drying curves. 


\section{RESULTS AND DISCUSSIONS}

\section{Drying air characteristics.}

There were a continuously variation in the drying air characteristics through the solar drying experiments due to the continuously changing in the ambient air characteristics. Since the ambient air temperature ranged from 21.8 to $38.5^{\circ} \mathrm{C}$, ambient air relative humidity from 10.5 to $48.5 \%$, while, the drying air from 31.2 to $49.8^{\circ} \mathrm{C}$, drying air relative humidity from 6.5 to $38.5 \%$. The average solar radiation was ranged 200-800 $\mathrm{W} / \mathrm{m}^{2}$ and the average speed of ambient air was about $1.5 \mathrm{~m} / \mathrm{s}$. The maximum difference between the ambient air temperature and the drying air temperature was $10.3^{\circ} \mathrm{C}$. The average air flow rate through the drying chamber was $2 \mathrm{~m}^{3} / \mathrm{min}$.

The relationship between the temperature of ambient air and the temperature of drying air inside the solar dryer during the whole period of solar radiation and the drying process

$$
\mathrm{T}(\text { drying air })=2.06 \mathrm{~T}_{(\mathrm{amb} . \text { air })}-24.52 \quad\left(\mathrm{R}^{2}=0.964\right)
$$

The relationship between the relative humidity of ambient air and the relative humidity of drying air (\%) inside the solar dryer

$$
\mathrm{RH}(\text { drying air })=1.29 \mathrm{RH}_{(\mathrm{amb} . \text { air })}-24.82 \quad\left(\mathrm{R}^{2}=0.889\right)
$$

The weather conditions during the solar drying experiments for Navel and Minneola orange slices were shown in Figs. (2 and 3).

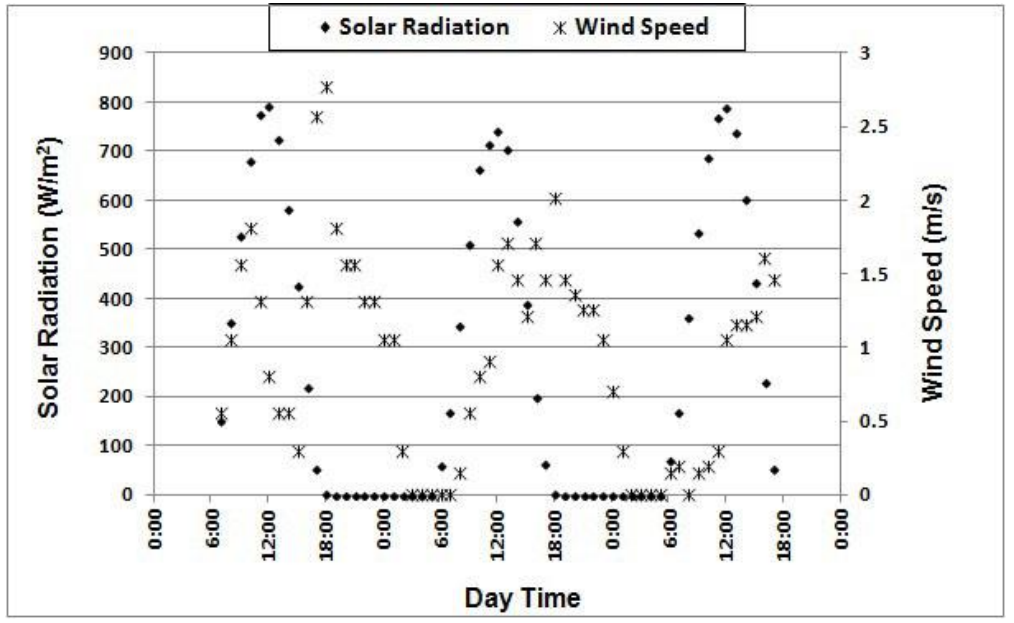

Fig. 2. The changes in the direct radiation and wind speed. 


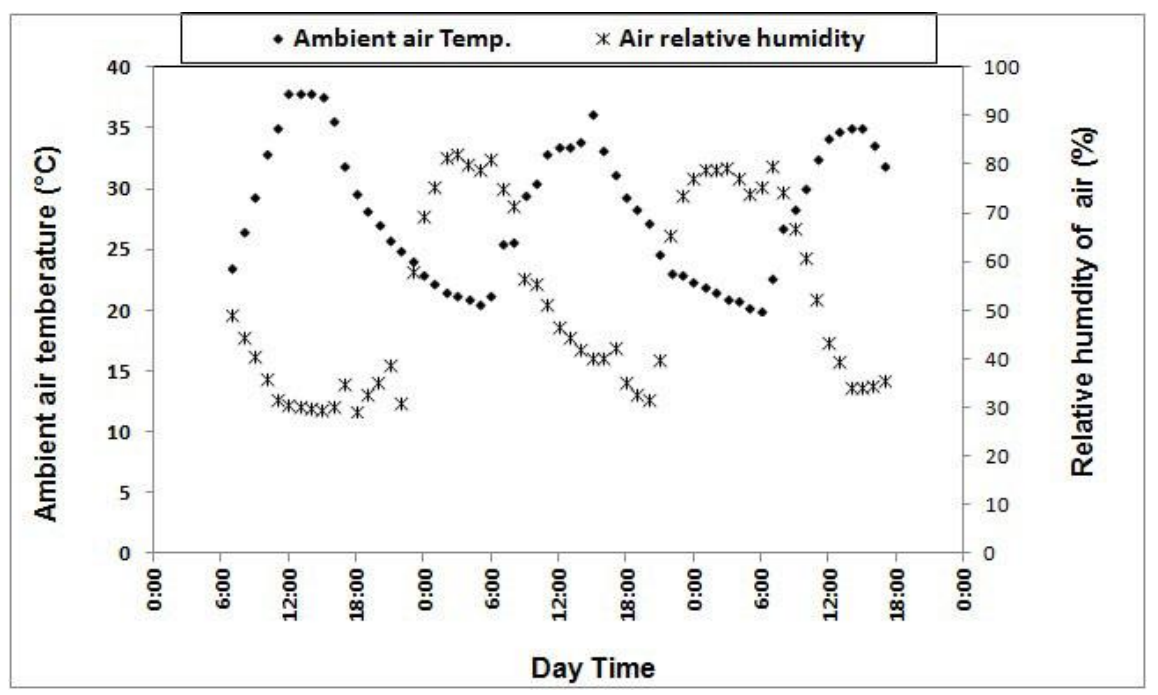

Fig. 3. Changes in the ambient air temperature \& relative humidity.

\section{Drying rate.}

Figures (4 and 5) present the mean moisture content versus drying time (drying rate for sliced Navel and Minneola oranges (3, 6, $9 \mathrm{~mm}$ thickness) dried by solar dryer. The total drying times required to reach final moisture content $(21.30,21.90$, and $33.78 \%)$ were (40, 52 and $78 \mathrm{~h}$ ) for 3, 6, $9 \mathrm{~mm}$ thickness of Navel orange slices, respectively. The total drying times required to reach final moisture content $(18.73,19.5$, and $28.53 \%$ ) were $(32,44$ and $59 \mathrm{~h})$ for 3, 6, $9 \mathrm{~mm}$ thickness of Minneola slices, respectively.

The mean drying rate versus drying time for Navel and Minneola orange slices as shown in Fig. 4 ( $a$ and b). The data indicated that, the drying time for Minneola is shorter than for Navel orange. The results indicated also that, the drying rate was decreased during the drying time (similar to Ceylan et al., 2007) for tropical fruits and the drying rates were too low during the first hours due to the low value of solar radiation on the collection in the morning and as the drying chamber warmed up. The maximum drying rate occurred between 2 to 8 hours, and corresponded to the drying chamber reaching its maximum temperature during the hottest pant of the day Fig. 4 ( $a$ and $b$ ). 


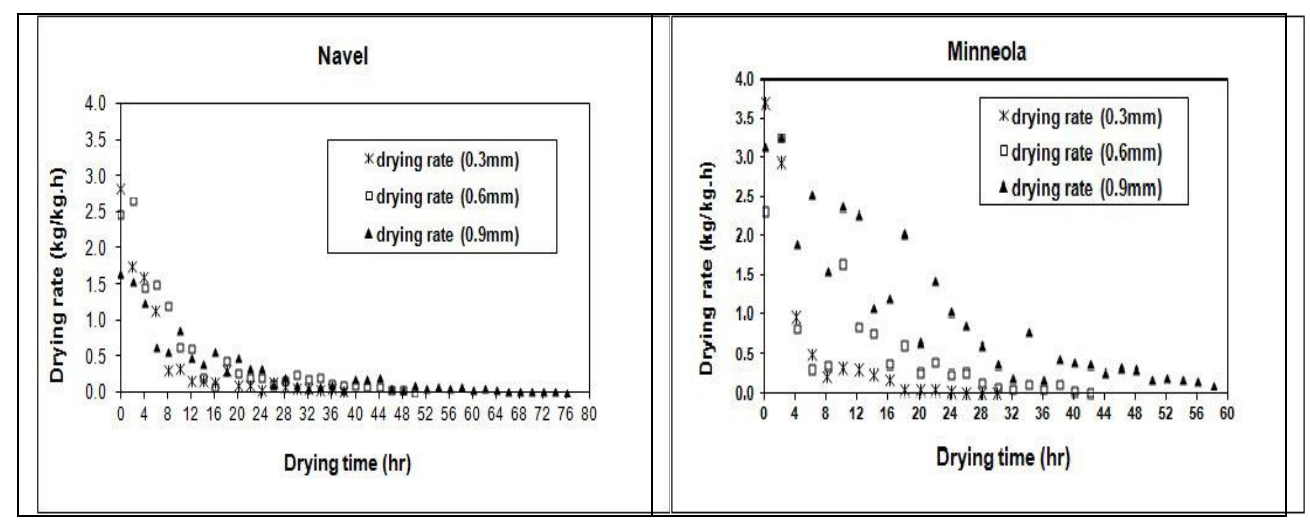

Fig (4). Drying rate versus drying time for orange slices (a) Navel. (b) Minneola. ( $\times 3 \mathrm{~mm}, \square 6 \mathrm{~mm} \& \triangle 9 \mathrm{~mm}$ thickness)

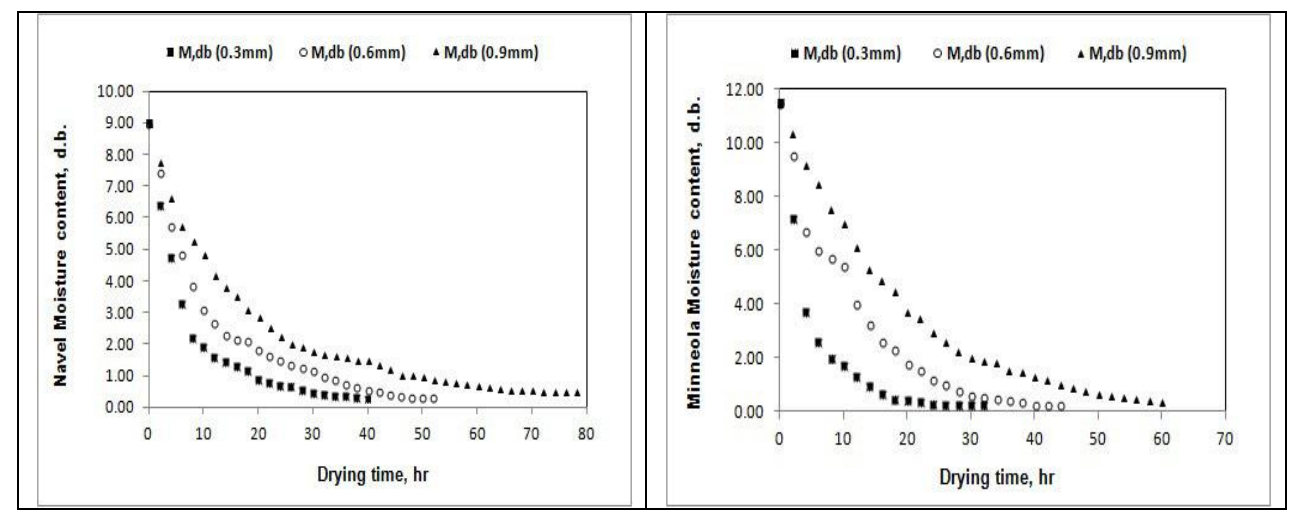

Fig (5). Drying time versus moisture content, d.b. for oranges slices. (a) Navel (b) Minneola. ( $\times 3 \mathrm{~mm}, \square 6 \mathrm{~mm} \& \Delta 9 \mathrm{~mm}$ thickness)

The data indicated that, the differences in drying rate between all treatments were small. Fig. 5 ( $a$ and $b$ ) show the relation between moisture content and drying rate of 3,6, and $9 \mathrm{~mm}$ thickness slices for the different pretreatments. Examination of Fig. 5 ( $a$ and $b$ ) reveals that in the first 12 hours the extent of moisture content reduction was significantly dependent on the slices thickness. The order of rate of moisture loss was $3 \mathrm{~mm}>6 \mathrm{~mm}>9 \mathrm{~mm}$. After 12 hours of drying, further loss in moisture was minimal in $3 \mathrm{~mm}$ thick slices. Slight moisture reduction continued for 6 and $9 \mathrm{~mm}$ thick slices. 


\section{Mathematical modeling of drying rates.}

For the semi-theoretical 9 models given in Table (1), standard error of estimate (SEE) and coefficient of determination $\left(R^{2}\right)$ were calculated by the computer program (Spss 16) and are given in Tables (2\&3). As shown in Tables (2 and 3), the best $R^{2}$ value for Navel and Minneola orange slices is proved by the Page (P) and two-term (TT) models. The moisture content data of the different fresh samples and different thickness converted to a moisture ratio then fitted against the drying time.

The Two Term, Page, and page models gave a higher $R^{2}$ and lower $\chi^{2}$ and RMSE as shown in Tables (2 and 3), so they were chosen to represent the solar drying behavior for thin layer drying of Navel and Minneola orange slices. The values of constants $\mathrm{k}\left(\mathrm{min}^{-1}\right), \mathrm{a}, \mathrm{b}, \mathrm{c}, \mathrm{k}_{1}, \mathrm{k}_{2}, \mathrm{n}$ (dimensionless) for the models were determined also using multiple regression. The multiple combinations of different parameters which gave the highest $\mathrm{R}^{2}$ were finally included in the model. All possible combinations of the different parameters that gave the higher $R^{2}$ were finally included in the best models. So, the moisture content of Navel and Minneola oranges at any time during the drying process could be estimated. The coefficients of determination $R^{2}$, the RMSE and the $\chi^{2}$ for the nine models for the non-linear regression was used to fit drying curves to the data are presented in Tables (2 and 3).

Therefore, the moisture content of the Navel and Minneola oranges (3mm, thickness) at any time during the drying process could be determined within the experimental boundary conditions. Validation of the Page (P) and two-term (TT) models were established by comparing the estimated and predicted moisture ratio at any particular drying condition. The validation of the Page (P) and two-term (TT) models for different slice thickness are shown in Fig. 6. The predicted data generally banded around the straight line which showed the suitability of the Page and Two Term models in describing the drying behavior of the Minneola and Navel orange slices ( $3 \mathrm{~mm}$ thickness). 
Table (2). Models, coefficients, coefficient of determination $\left(\mathbf{R}^{2}\right)$, chi-square $\left(\chi^{2}\right)$ and root mean square error (RMSE) of Navel drying.

\begin{tabular}{|c|c|c|c|c|c|c|c|c|c|c|c|c|c|}
\hline \multirow[t]{2}{*}{ Slicing } & \multicolumn{9}{|c|}{ Coefficients } & \multirow[t]{2}{*}{ Modal } & \multirow[t]{2}{*}{$\mathbf{R}^{2}$} & \multirow[t]{2}{*}{$\chi^{2}$} & \multirow[t]{2}{*}{ RMSE } \\
\hline & $\mathbf{a}$ & b & $\mathbf{C}$ & $\mathbf{G}$ & $\mathbf{h}$ & $\mathbf{k}$ & $\mathbf{K}_{\mathbf{0}}$ & $\mathbf{K}_{1}$ & $\mathbf{n}$ & & & & \\
\hline \multirow{9}{*}{$\begin{array}{c}3 \\
(\mathbf{m m})\end{array}$} & & & & & & 0.234 & & & & $N$ & 0.984 & $5.85 \mathrm{E}-05$ & 0.04036 \\
\hline & & & & & & 0.242 & & & 0.765 & $P$ & 0.991 & $7.65 \mathrm{E}-06$ & 0.02396 \\
\hline & 0.953 & & & & & 0.140 & & & & $\mathrm{HP}$ & 0.976 & $5.14 \mathrm{E}-05$ & 0.03858 \\
\hline & 0.938 & & 0.053 & & & 0.175 & & & & $L$ & 0.993 & $4.06 \mathrm{E}-06$ & 0.02018 \\
\hline & 0.245 & 0.765 & & & & & 0.050 & 0.234 & & $T T$ & 0.997 & 8.85E-07 & 0.01359 \\
\hline & 5.141 & -4.162 & -0.011 & 0.156 & 0.129 & 0.156 & & & & $W S$ & 0.990 & $1.18 \mathrm{E}-05$ & 0.02518 \\
\hline & 1.01 & 0.001 & & & & 0.219 & & & 0.841 & $M$ & 0.994 & $3.91 \mathrm{E}-06$ & 0.01970 \\
\hline & & & & & & 0.011 & & & 13.041 & $M P$ & 0.973 & $7.65 \mathrm{E}-06$ & 0.02396 \\
\hline & -0.077 & 0.001 & & & & & & & & $M H P$ & 0.766 & $4.68 \mathrm{E}-03$ & 0.11914 \\
\hline \multirow{9}{*}{$\begin{array}{c}\mathbf{6} \\
(\mathrm{mm})\end{array}$} & & & & & & 0.089 & & & & $N$ & 0.972 & 7.91E-05 & 0.04098 \\
\hline & & & & & & 0.157 & & & 0.784 & $P$ & 0.993 & $5.66 \mathrm{E}-06$ & 0.02099 \\
\hline & 0.933 & & & & & 0.082 & & & & $H P$ & 0.977 & $5.54 \mathrm{E}-05$ & 0.03712 \\
\hline & 0.923 & & 0.057 & & & 0.105 & & & & $L$ & 0.990 & $1.14 \mathrm{E}-05$ & 0.02473 \\
\hline & 0.470 & 0.549 & & & & & 0.048 & 0.195 & & $T T$ & 0.997 & $1.14 \mathrm{E}-06$ & 0.01377 \\
\hline & 0.264 & 0.753 & 0.612 & 0.159 & 0.004 & 0.013 & & & & $W S$ & 0.996 & $6.32 \mathrm{E}-06$ & 0.01461 \\
\hline & 1.02 & $3.1 \mathrm{E}-4$ & & & & 0.158 & & & 0.797 & $M$ & 0.993 & $4.97 \mathrm{E}-06$ & 0.01989 \\
\hline & & & & & & 0.112 & & & 0.794 & $M P$ & 0.972 & $5.66 \mathrm{E}-06$ & 0.02099 \\
\hline & -0.054 & 0.001 & & & & & & & & $M H P$ & 0.840 & $2.71 \mathrm{E}-03$ & 0.09823 \\
\hline \multirow{9}{*}{$\begin{array}{c}9 \\
(\mathbf{m m})\end{array}$} & & & & & & 0.054 & & & & $N$ & 0.972 & $9.95 \mathrm{E}-05$ & 0.03946 \\
\hline & & & & & & 0.109 & & & 0.778 & $P$ & 0.997 & $1.54 \mathrm{E}-06$ & 0.01383 \\
\hline & 0.911 & & & & & 0.049 & & & & $H P$ & 0.981 & $4.45 \mathrm{E}-05$ & 0.03206 \\
\hline & 0.90 & & 0.064 & & & 0.064 & & & & $L$ & 0.996 & $2.32 \mathrm{E}-06$ & 0.01522 \\
\hline & 0.409 & 0.585 & & & & & 0.027 & 0.103 & & $T T$ & 0.998 & 3.62E-07 & 0.00950 \\
\hline & 0.534 & 0.463 & 1.224 & 0.120 & $-1.8 \mathrm{E}-4$ & 0.035 & & & & $W S$ & 0.998 & $4.55 \mathrm{E}-06$ & 0.01764 \\
\hline & 1.01 & $4.1 \mathrm{E}-4$ & & & & 0.10 & & & 0.825 & $M$ & 0.998 & $4.86 \mathrm{E}-07$ & 0.01022 \\
\hline & & & & & & 0.013 & & & 4.231 & $M P$ & 0.972 & $1.54 \mathrm{E}-06$ & 0.01383 \\
\hline & -0.036 & $3.2 \mathrm{E}-4$ & & & & & & & & $M H P$ & 0.869 & $2.19 \mathrm{E}-03$ & 0.08489 \\
\hline
\end{tabular}


Table (3). Models, coefficients, coefficient of determination $\left(\mathbf{R}^{2}\right)$, chi-square $\left(\chi^{2}\right)$ and root mean square error (RMSE) of Minneola drying.

\begin{tabular}{|c|c|c|c|c|c|c|c|c|c|c|c|c|c|}
\hline \multirow[t]{2}{*}{ Slicing } & \multicolumn{9}{|c|}{ Coefficients } & \multirow[t]{2}{*}{ Modal } & \multirow[t]{2}{*}{$\mathbf{R}^{2}$} & \multirow[t]{2}{*}{$\chi^{2}$} & \multirow[t]{2}{*}{$R M S E$} \\
\hline & A & $\mathbf{b}$ & C & $\mathbf{G}$ & $\mathbf{h}$ & $\mathbf{k}$ & $\mathrm{K}_{0}$ & $\mathrm{~K}_{1}$ & $\mathbf{n}$ & & & & \\
\hline \multirow{9}{*}{$\begin{array}{c}3 \\
(\mathrm{~mm})\end{array}$} & & & & & & 0.234 & & & & $N$ & 0.984 & $2.01 \mathrm{E}-05$ & 0.03248 \\
\hline & & & & & & 0.33 & & & 0.793 & $P$ & 0.992 & 4.87E-06 & 0.02242 \\
\hline & 0.977 & & & & & 0.228 & & & & $H P$ & 0.984 & $2.01 \mathrm{E}-05$ & 0.03196 \\
\hline & 0.962 & & -0.033 & & & 0.259 & & & & $L$ & 0.992 & $5.20 \mathrm{E}-06$ & 0.02239 \\
\hline & 0.266 & 0.743 & & & & & 0.094 & 0.36 & & $T T$ & 0.996 & $1.61 \mathrm{E}-06$ & 0.01639 \\
\hline & 0.753 & 0.256 & 0.048 & 0.091 & 0.001 & 0.357 & & & & $W S$ & 0.996 & $1.90 \mathrm{E}-06$ & 0.01639 \\
\hline & 1 & 0.001 & & & & 0.315 & & & 0.839 & $M$ & 0.994 & $3.98 \mathrm{E}-06$ & 0.02056 \\
\hline & & & & & & 0.012 & & & 19.13 & $M P$ & 0.984 & 4.87E-06 & 0.02242 \\
\hline & -0.102 & -0.968 & & & & & & & & MHP & 0.715 & $6.67 \mathrm{E}-03$ & 0.13639 \\
\hline \multirow{9}{*}{$\begin{array}{c}6 \\
(\mathrm{~mm})\end{array}$} & & & & & & 0.093 & & & & $N$ & 0.987 & $2.21 \mathrm{E}-05$ & 0.03095 \\
\hline & & & & & & 0.109 & & & 0.939 & $P$ & 0.988 & $1.91 \mathrm{E}-05$ & 0.02951 \\
\hline & 0.971 & & & & & 0.090 & & & & $H P$ & 0.988 & $1.98 \mathrm{E}-05$ & 0.02976 \\
\hline & 0.974 & & -0.006 & & & 0.088 & & & & $L$ & 0.988 & $2.05 \mathrm{E}-05$ & 0.02967 \\
\hline & -0.003 & 0.971 & & & & & -0.013 & 0.089 & & $T T$ & 0.988 & $2.16 \mathrm{E}-05$ & 0.02966 \\
\hline & 0.112 & 0.894 & -0.223 & 0.081 & -0.002 & 0.667 & & & & $W S$ & 0.987 & $2.66 \mathrm{E}-05$ & 0.02983 \\
\hline & 0.995 & $-6.2 \mathrm{E}-4$ & & & & 0.117 & & & 0.895 & $M$ & 0.989 & $1.78 \mathrm{E}-05$ & 0.02828 \\
\hline & & & & & & 0.011 & & & 8.174 & $M P$ & 0.987 & $1.91 \mathrm{E}-05$ & 0.02951 \\
\hline & -0.061 & 0.001 & & & & & & & & $M H P$ & 0.942 & $2.31 \mathrm{E}-05$ & 0.03095 \\
\hline \multirow{9}{*}{$\begin{array}{c}9 \\
(\mathrm{~mm})\end{array}$} & & & & & & 0.054 & & & & $N$ & 0.999 & $5.43 \mathrm{E}-06$ & 0.02029 \\
\hline & & & & & & 0.049 & & & 1.035 & $P$ & 0.999 & $1.66 \mathrm{E}-07$ & 0.00841 \\
\hline & 1.011 & & & & & 0.055 & & & & $H P$ & 0.999 & $2.66 \mathrm{E}-07$ & 0.00946 \\
\hline & 1.016 & & -0.009 & & & 0.054 & & & & $L$ & 0.999 & $2.32 \mathrm{E}-07$ & 0.00906 \\
\hline & 0.227 & 0.784 & & & & & 0.055 & 0.055 & & $T T$ & 0.999 & $2.85 \mathrm{E}-07$ & 0.00946 \\
\hline & 0.561 & 0.447 & -0.080 & 0.054 & -0.001 & 0.054 & & & & $W S$ & 0.999 & $9.52 \mathrm{E}-07$ & 0.01254 \\
\hline & 0.995 & $8.3 \mathrm{E}-5$ & & & & 0.046 & & & 1.052 & $M$ & 0.999 & $1.70 \mathrm{E}-07$ & 0.00831 \\
\hline & & & & & & 0.004 & & & 14.26 & $M P$ & 0.999 & $1.66 \mathrm{E}-07$ & 0.00842 \\
\hline & -0.040 & $4.2 \mathrm{E}-4$ & & & & & & & & $M H P$ & 0.983 & $5.58 \mathrm{E}-05$ & 0.03602 \\
\hline
\end{tabular}



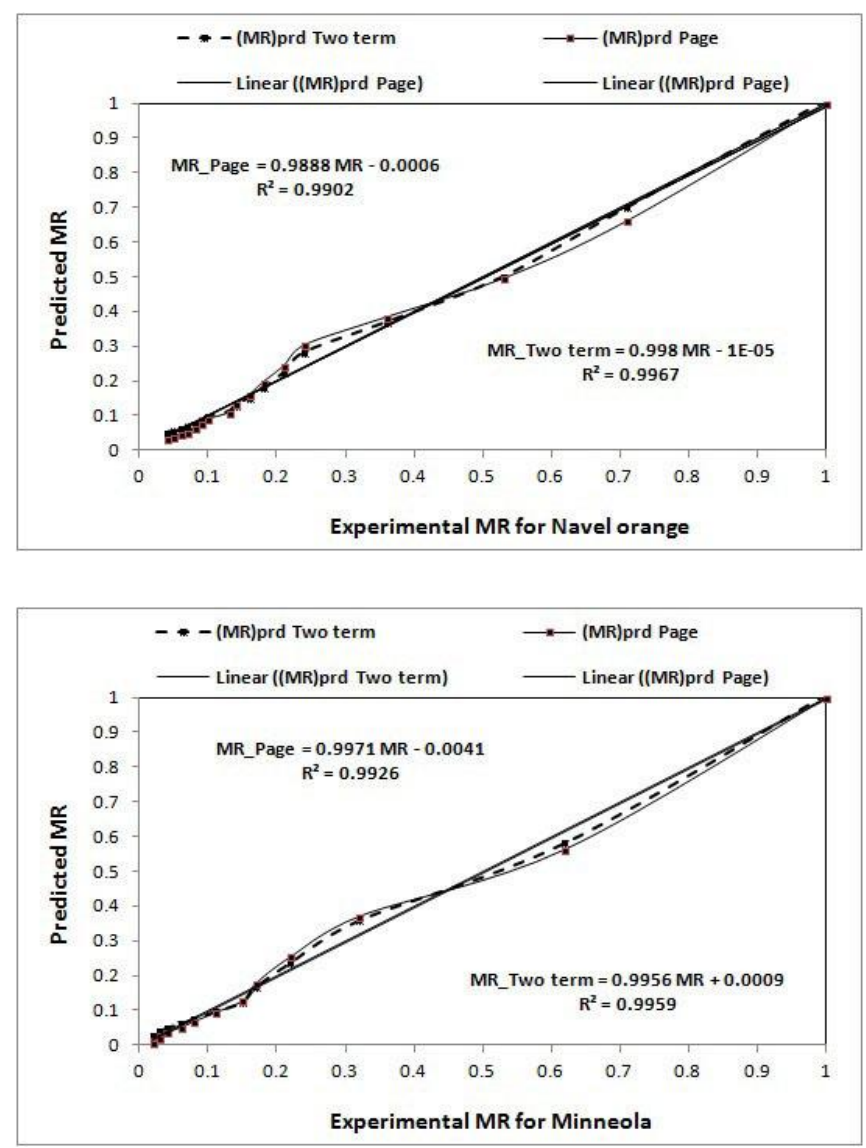

Fig (6). Comparison of experimental moisture ratio with predicted moisture ratio by * Two Term (TT) \& $\square$ Page (P) models (3 mm slices) for (a) Navel (b) Minneola.

Except Modified Henderson \& Pabis model (MHP), all fitted curves agreed well with the experimental values (The $R^{2}$ values were higher than 0.97). However, the $R^{2}$, RMSE and $\chi^{2}$ for these models were always significantly different to the corresponding values for the other models. This indicates that these models were not adequately describing the drying curves of oranges for all treatments. Based on these results, the Page (P) and two-term (TT) models were selected as the best models to represent the drying of Navel and Minneola orange slices. The Page and Two-Term models predicted moisture contents closely, matching the experimental values for all treatments. These results for Page model were 
matched well to those of Ceylan et al., (2007) for tropical fruits, Aghbashlo et al., (2009) potato slices, Doymaz and Ismail (2011) for sweet cherry and for Two-term model according to Kucerova et al., (2015) for Jerky. In addition, the results for both models matching with Hii et al. (2009) for cocoa.
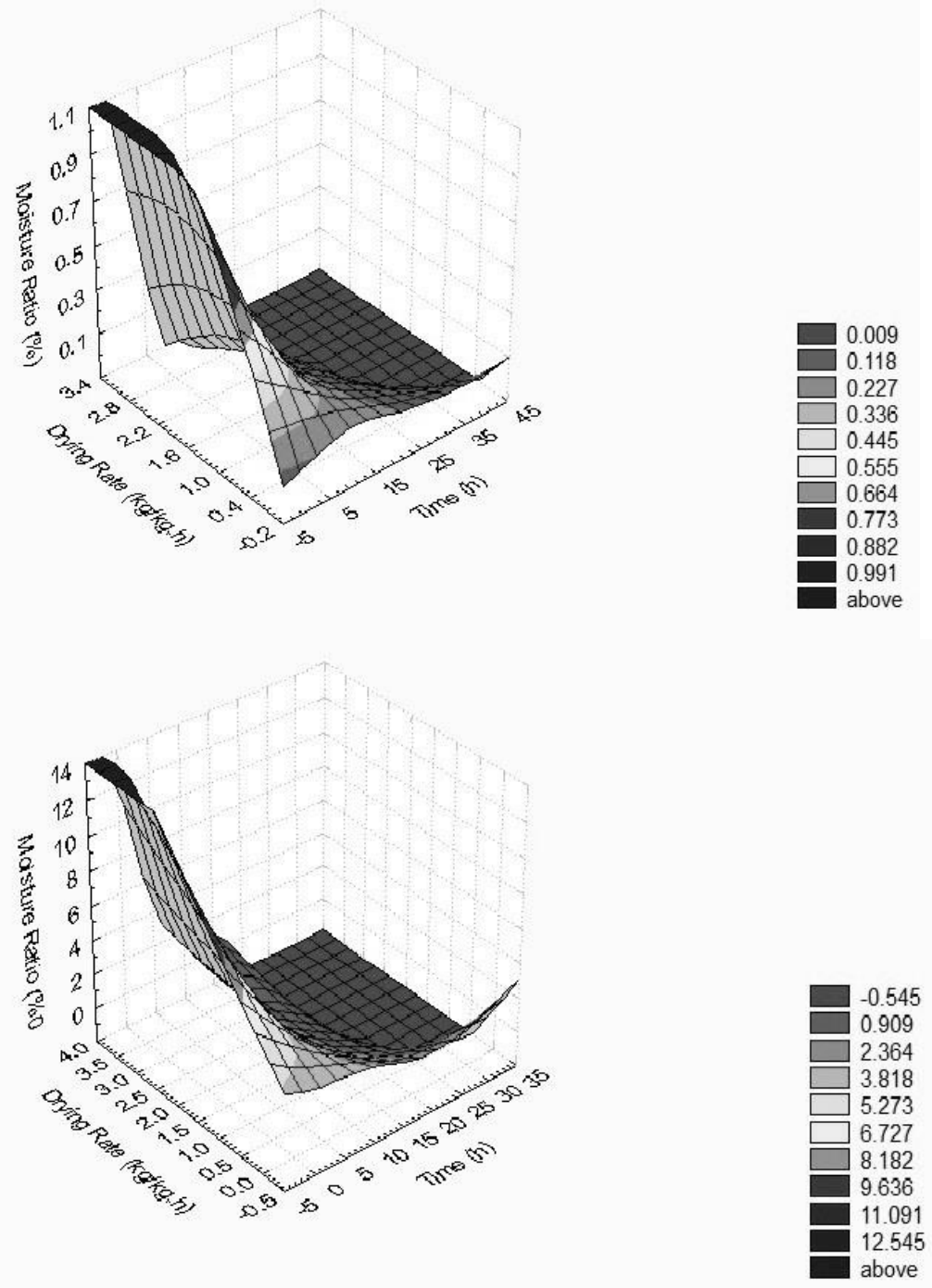

Fig. 7. Response surface plots showing the significant $(p \leq 0.05)$ interaction effects on the moisture ratio and drying rate under exposure time for (a) Navel. (b) Minneola. 
The relation between moisture ratio (\%) and drying rate $(\mathrm{kg} / \mathrm{kg} . \mathrm{h})$ with exposure time (h) for orange Navel are shown in Fig. $(7, a)$ and for Minneola in Fig. $(7, b)$.. It can be noticed that, increase of moisture ratio increased the drying rate and exposure time. And show that, the values of the moisture ratio increased the drying rate for Navel Fig. $(7, a)$ and Minneola Fig. $(7, b)$ presented as contour (line dark) red on the horizontal plane. The findings also showed that exposure time increased the drying rate increaseduntil $15 \mathrm{~h}$ and then constant increased. The most significant $(p \leq 0.05)$ effect on moisture ratio was revealed to be the linear effect of drying rate followed by the quadratic effect of drying rate.

It seems also, the drying rate take exposure time less than navel to dried. The moisture ratio of Minneola show strong dependence on both drying rate and time of exposure.

\section{CONCLUSIONS}

The Page (P) and two-term (TT) models were considered the best models to represent the drying behavior of Navel and Minneola orange slices due to the significant parameter values given by the model constants in the fitted model represented the equilibrium moisture content, the moisture to be removed, and the drying rate of orange slices. The determination coefficient $R^{2}$, Chi-square $\left(\chi^{2}\right)$ and the root mean square error (RMSE) were calculated to evaluate the models. The results showed the drying rate was decreased during the drying time and for increasing drying rate, orange could be sliced to $3 \mathrm{~mm}$. The results also indicated that, the drying time for Minneola is shorter than for Navel orange. The moisture ratio of Navel and Minneola orange slices shows the strong dependence on both drying rate and time of exposure.

The Recommendation from this research that the drying solar could be used for Navel and Minneola orange slices with a good impact on the drying kinetics and the quality of the dried products.

\section{REFERENCES}

Aghbashlo M., Kianmehr, M.H. \& Arabhosseini, A. (2009). Modeling of thin-layer drying of potato slices in length of continuous band dryer. Energy Conversion and Management, 50, 1348-1355. 
Amer, B. M. A., Hossain, M. A. \& Gottschalk, K. (2010). Design and performance evaluation of a new hybrid dryer for banana. Energy Conversion and Management, 2010, 51(4): 813-820.

AOAC (2003). Official methods of analysis (16th ed.). Washington, DC, USA: Association of Official Analytical Chemists.123-135.

Benhura, C., Kugara, J., Muchuweti, M., Nyagura, S. F., Matarise, F., Gombiro, P.E. and Nyandoro, G. (2014). Drying kinetics of syrup of Parinari curatellifolia fruit and cereal based product, zvambwa. Journal of Food Science and Technology, 51:

Ben Slama, R. and Combarnous, M. (2011). Study of orange peels dryings kinetics and development of a solar dryer by forced convection. Solar Energy, 85, 570-578.

Ceylan, I., Aktas, M., and Dogan, H. (2007). Mathematical modeling of drying characteristics of tropical fruits. Applied Thermal Engineering, (27):1931-1936.

Chimplee, S., and Klinkesorn, U., (2015). Thin-layer drying model of Rambutan (Nephelium lappaceum L.) kernel and its application in fat extraction process. International Journal of Food Engineering, 11(2): 243-253.

Davies, F.S., 1997. An overview of climatic effects on citrus flowering and fruit quality in various parts of the world. In: Citrus Flowering and Fruiting Short Course, 1., Lake Alfred. Proceedings. CREC/IFAS, Lake Alfred.

Diamante, L.M., and Munro, P.A. (1993). Mathematical modeling of the thin layer solar drying of sweet potato slices. Solar Energy, 51, 271-276.

Diamante, L.M., Ihns, R., Savage, G.P., and Vanhanen, L., (2010). A new mathematical model for thin layer drying of fruits. International Journal of Food Science and Technology, 45 (9), 1956-1962. 
Doymaz, I., and Pala, M. (2002). The effects of dipping pretreatments on air drying rates of the seedless grapes. Journal of Food Engineering, 52, 413-417.

Doymaz, I., and Ismail, O., (2011). Drying characteristics of sweet cherry. Food and Bioproducts Processing, 89, 31-38.

El-Beltagy A., Gamea, G.R and Amer Eissa A.H. (2007). Solar drying characteristics of strawberry. Journal of Food Engineering, 78 (2007) 456-464.

Ertekin, C., and Yaldiz, O. (2004). Drying of eggplant and selection of suitable thin layer drying model. Journal of Food Engineering 63(3), 349-359.

Gallali, Y. M., Abujnah Y. S, and Bannani F. K. (2000). Preservation of fruits and vegetables using solar drier: a comparative study of natural and solar drying, III; chemical analysis and sensory evaluation data of the dried samples (grapes, figs, tomatoes and onions). Renewable Energy,19:203-12.

Garau, M.C., Simal, S., Femenia, A. and Rossello, C. (2006). Drying of orange skin: drying kinetics modeling and functional properties. Journal of Food Engineering, 75, 288-295.

Goyal, R.K., Kingsly, A.R.P., Manikantan, M.R. and Ilyas, S.M., (2007). Mathematical modeling of thin layer drying kinetics of plum in a tunnel dryer. Journal of Food Engineering 79: 176-180.

Hii, C.L., Law, C.L. and Cloke, M. (2009). Modeling using a new thin layer drying model and product quality of cocoa. Journal of Food Engineering, 90, 191-198.

Jackson L. K. and Futch S. H. (2003). Minneola Tangelo. HS171, the Horticultural Sciences Department, UF/IFAS Extension. University of Florida.

Karathanos, V.T. (1999). Determination of water content of dried fruits by drying kinetics. Journal of Food Engineering, 39(4), 337-344. 
Kucerova, I., Hubackova, A., Rohilik, B. and Banout, J. (2015). Mathematical Modeling of Thin-Layer Solar Drying of Eland (Taurotragus oryx) Jerky. Int. J. of Food Eng. 11(2), 229-242.

Madamba, P.S., Driscoll, R.H., and Buckle, K.A. (1996). The thin layer drying characteristics of garlic slices. Journal of Food Engineering, 29, 75-97.

Mahmutogla, T., Emir, F., and Saygi, Y. B. (1996). Sun/solar dryer of differently treated grapes and storage stability of dried grapes. Journal of Food Engineering, 29, 289-300.

Midilli A., Kucuk H. and Yapar Z. (2002). A new model for single layer drying. Drying Technology, 20: 1503-1513.

Ozdemir, M., and Devers, Y.O. (1999). The thin layer drying characteristics of hazelnuts during roasting. Journal of Food Engineering, 42, 225-233.

Rodriguez-Amaya, D.B. (1999). A guide to carotenoid analysis in foods. International life Sciences Institute Press, p.59. Washington, DC.

Sanchez-Moreno, C., Plaza, L., De Ancos, B., and Cano, M.P. (2003). Vitamin C, provitamin A carotenoids, and other carotenoids in high pressure orange juice during refrigerated storage. Journal of Agricultural and Food Chemistry, 51(3), 647-653.

Sarsavadia, P.N., Sawhney, R. L., Pangavhane, D.R., and Singh, S.P. (1999). Drying behavior of brined onion slices. Journal of Food Engineering, 40, 219-226.

Shi, Q., Zheng, Y., and Zhao, Y. (2013). Mathematical modeling on thin-layer heat pump drying of yacon (Smallanthus sonchifolius) slices. Energy Conversion and Management, 71, 208-216.

Taghian Dinani, S., Hamdami, N., Shahedi, M., and Havet, M. (2014). Mathematical modeling of hot air/electrohydrodynamic (EHD) drying kinetics of mushroom slices. (2004). Energy Conversion and Management, 86, 70-80. 
Togrul, I.T. and Pehlivan, D. (2004). Modelling of thin layer drying of some fruits under open-air sun drying process. Journal of Food Science and Technology, 65:413-425.

Turner, I., and Mujumdar, A.S. (1997). Mathematical modeling and numerical techniques in drying technology. Marcel Dekker. New York.

Yagciolu, A., Degirmencioglu, A. and Cagatay, F. (1999). Drying characteristics of laurel leaves under different conditions. In Proceedings of the 7th International Congress on Agricultural Mechanization and Energy, May, Adana, Turkey (pp. 565-569).

Yaldiz, O., Ertekin, C., and Uzun, H.I. (2001). Mathematical modeling of thin layer solar drying of sultara grapes. Energy, 26, 457-465.

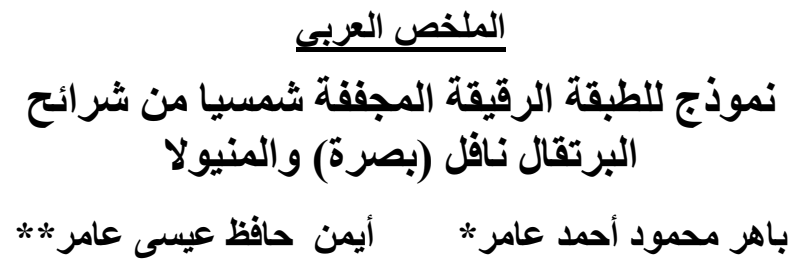

للمو الح وخاصة البرتقال أهمية كبيرة لأحتو ائها على عدة عناصر مهمة لجسم الانسان و أهمها

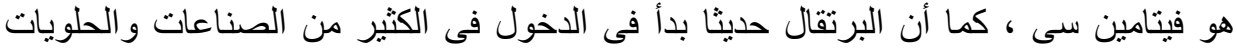

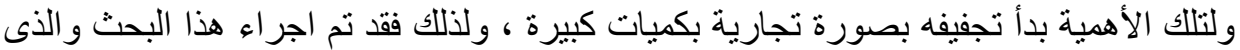

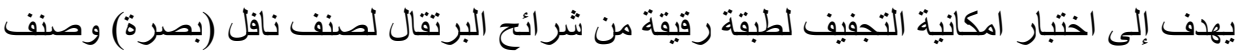

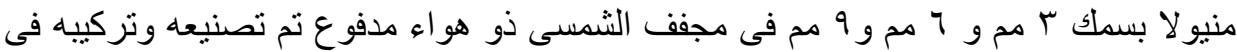

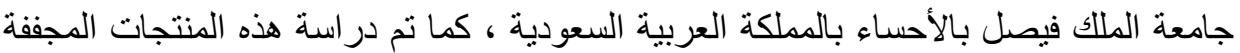

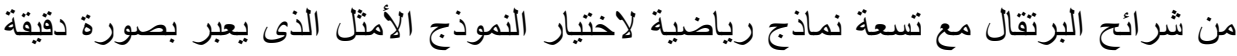

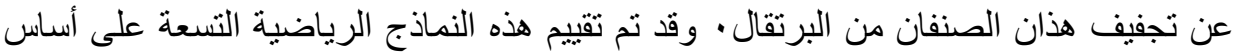

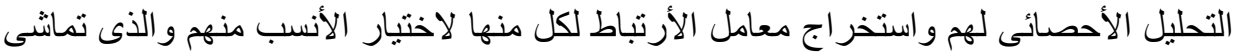

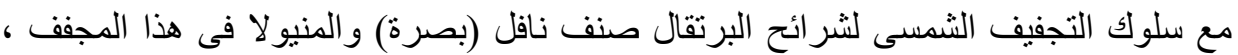
كما تم تقدير ثوابت التجفيف لكل نموذج من نماذج التجفيف التسعة المستخدمة فى هذه الدر اسة.

* استاذ الهندسة الزراعية المساعد, كلية الزراعة, جامعة القاهرة. ومعار بجامعة الملك فيصل بالمملكة العربية السعودية ** استاذ الهندسة الزراعية, كلية الزراعة, جامعة المنوفية. ومعار بجامعة الملك فيصل بالسعودية 
وقد وجد أن أفضل النماذج المعبرة عن ذلك هو نموذجى two-term و Page اعنمادا على

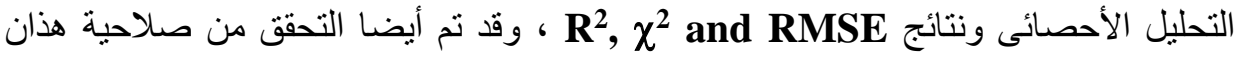
النمو ذجان مقارنة بالنتائج المتحصل عليها من البحث.

\section{وقد بينت الاراسة ما يلى:}

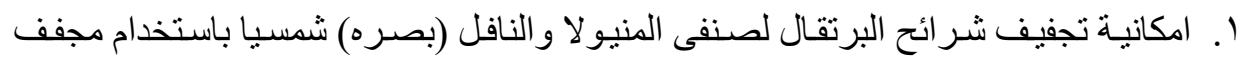

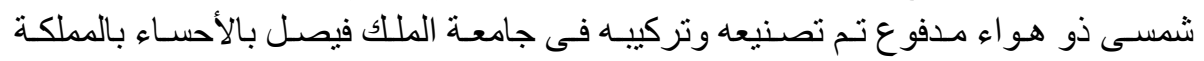

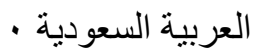

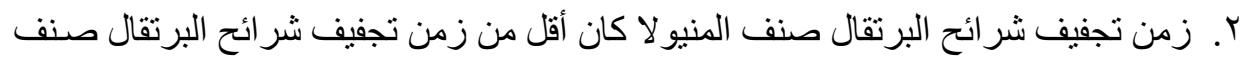

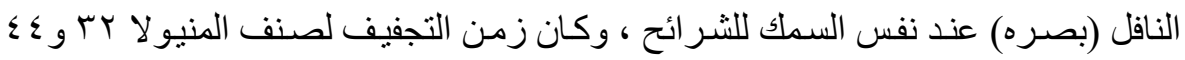

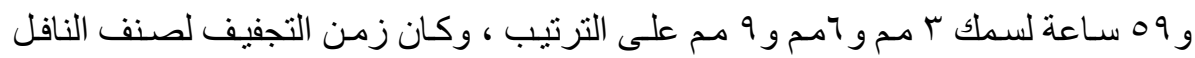

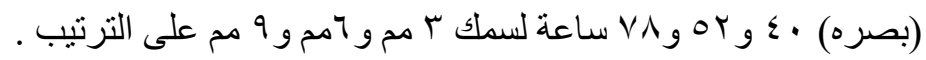

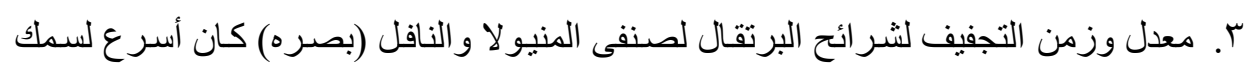

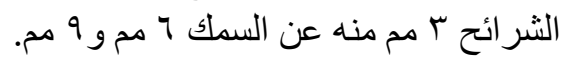
ع. يوجد ارتبـاط عـالي المعنويـة لثر ائح البرتقال لصنفى المنيو لا و النافل (بصره) بين نسبة التجفيف وكلا من معدل التجفيف وزمن التجفيف.

التوصيات :

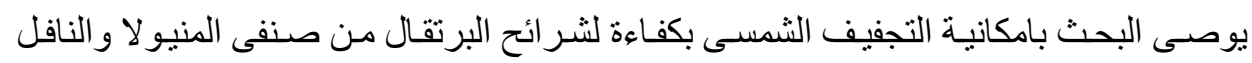

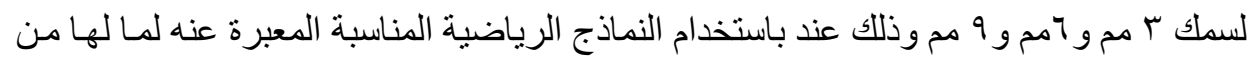

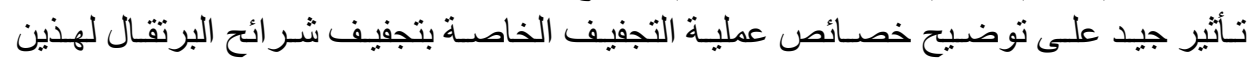

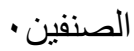

